\title{
EFFECTS OF IMMUNIZATION PROCEDURES IN EXPERIMENTAL TOXOPLASMOSIS*
}

\author{
ICHIRO NAKAYAMA \\ Department of Parasitology, School of Medicine, \\ Keio University, Tokyo
}

(Received for publication June 17, 1965)

\begin{abstract}
It has been well documented that prior infection of mice with Toxoplasma gondii strains of low virulence will protect against challenge infections with highly virulent strains (Weinman, 1943; Ruchman et al, 1948; Cutchins et al, 1956; Frenkel, 1956; Beverley, 1958; Ueda, 1960; Sato, 1963; Nakayama, 1964; Stahl et al, 1964). However, attempts to induce a comparable immunity via immunization procedures with toxoplasma antigens have not met as yet with complete success (Wildführ, 1957; Eichenwald, 1949).

In the present studies, investigations were made, as a re-examination and an extension of the latter studies, on the effects of : 1) several different toxoplasma antigens employed as vaccines, 2) the passive immunization of mice by antisera, and 3 ) the transfer of peritoneal exudate cells from immune mice to non-immune mice. In addition the invasion of Toxoplasma into immune cells was observed by diffusion chamber techniques.
\end{abstract}

\section{MATERIALS}

The source and preparation of the Beverley and RH strains of $T$. gondit were described previously (Nakayama, 1964). Albino mice weighing about $20 \mathrm{~g}$ were used in these experiment.

\section{METHODS AND RESULTS}

\section{Effect of Killed Toxoplasma Vaccine}

\section{Methods:}

Trophozoites of the RH strain of Toxoplasma were obtained from the abdominal cavity of infected mice, and were killed by heating in a water bath

* This research has been made possible through the support and sponsership of U.S. Department of Army, through its Far East Research Office. 
at $50^{\circ} \mathrm{C}$ for 30 minutes. A dose of this vaccine, containing 1 to $5 \times 10^{6}$ parasites in $0.2 \mathrm{ml}$ of saline, was injected subcutaneously in mice. This immunization process was repeated four times at intervals of 3 days. Challenge inoculation with $3,000 \mathrm{RH}$ trophozoites into the peritoneal cavity was carried out 2 to 7 weeks after the first vaccination. In addition, the effects of vaccination employing both complete and incomplete adjuvants were studied. These adjuvant vaccines, containing approximately $5 \times 10^{6}$ killed parasites in 0.2 $\mathrm{ml}$, were inoculated subcutaneously, being followed by booster injections with $3 \times 10^{6}$ killed parasites 3 weeks later. Challenge injection was performed by intraperitoneal inoculation of $3,000 \mathrm{RH}$ trophozoites 4 weeks after the first vaccination.

Both the experimental and control mice were observed for 3 weeks, and dead mice were examined for the presence of parasites in the abdominal cavity and the brain. Mice surviving for 3 weeks were killed, and their whole brains were subinoculated into clean mice to test for the presence of parasites.

Results:

In the case of vaccination without adjuvants, only 6 mice out of 158 survived the challenge, as shown in Table 1 . The survivals were seen in mice received the challenge within a relatively short period after vaccination, i.e. within 3 weeks. None of 80 mice which were challenged between 4 and 7 weeks after vaccination survived 3 weeks. By subinoculations of the brains of surviving mice into clean mice, it was revealed that living parasites were present in all but 1 mouse. All of 110 control mice died within 10 days after the $\mathrm{RH}$ inoculation.

After injection of vaccine in incomplete adjuvant and subsequent booster injection only 3 of 77 mice survived the challenge. One of these 3 mice was

Table 1

Efficacy of a Killed-vaccine in Protecting Mice against. Challenge with the RH Strain of T. gondii

\begin{tabular}{|c|c|c|c|c|c|}
\hline \multirow{2}{*}{\multicolumn{2}{|c|}{$\begin{array}{l}\text { Period between } \\
1 \text { st vaccination } \\
\text { and challenge }\end{array}$}} & \multirow{2}{*}{ No. of mice } & \multicolumn{3}{|c|}{ No. of mice surviving } \\
\hline & & & $1 \mathrm{wk}$ & 2 wks & 3 wks \\
\hline \multicolumn{2}{|c|}{ Controls } & 110 & $69(63 \%)$ & 0 & - \\
\hline \multirow{5}{*}{ Exp. } & $2 \mathrm{wks}$ & 35 & $27(77 \%)$ & $1(3 \%)$ & $1(3 \%)$ \\
\hline & 3 & 43 & $38(88 \%)$ & $7(16 \%)$ & $5(12 \%)$ \\
\hline & 4 & 42 & $15(36 \%)$ & 0 & - \\
\hline & 5 & 20 & $9(45 \%)$ & 0 & - \\
\hline & 7 & 18 & $12(67 \%)$ & $1(6 \%)$ & 0 \\
\hline
\end{tabular}


shown to have parasites in the brain, while in the other 2 , no viable parasite was detected following subinoculation into clean mice, as shown in Table 2. After injection of vaccine in complete adjuvants, none of 48 mice survived for more than 2 weeks.

Table 2

Efficacy of a Killed-vaccine Plus Adjuvants in Protecting Mice against Challenge with the RH Strain of T. gondii

\begin{tabular}{l|c|c|c|c|c}
\hline \hline \multirow{2}{*}{ Adjuvants } & $\begin{array}{c}\text { Period between } \\
\text { 1st vaccination } \\
\text { and challenge }\end{array}$ & $\begin{array}{c}\text { Number } \\
\text { of } \\
\text { mice }\end{array}$ & \multicolumn{3}{|c|}{$\begin{array}{c}\text { Number of mice surviving } \\
\text { challenge }\end{array}$} \\
\hline Control 1 & (normal mice) & 40 & $20(50 \%)$ & 0 & - \\
Control 2 & (adjuvants only) & 34 & $19(56 \%)$ & $1(3 \%)$ & 0 \\
Incomplete & 4 weeks & 77 & $71(92 \%)$ & $4(5 \%)$ & $3(4 \%)$ \\
Complete & 4 weeks & 48 & $36(75 \%)$ & 0 & - \\
\hline
\end{tabular}

\section{Disrupted Toxoplasma Antigens}

\section{Methods:}

Toxoplasmas were taken from the abdominal cavity of $\mathrm{RH}$-infected mice, and pocled, and counted. The parasites were then disrupted by the exposure to sonic vibration for 5 minutes. The complete destruction of parasites was verified by both microscopical examination and subinoculation into clean mice. The suspension of $10-20 \times 10^{6}$ disrupted parasites was centrifuged for 10 minutes at 2,000 rpm, and the soluble antigens (supernatant) was separated from the insoluble antigens (sediment). Before its use, the sediment was washed with saline. The supernatant and sediment antigens were then wellemulsified with either complete or incomplete adjuvants, and injected subcutaneously in aliquots of $0.2 \mathrm{ml}$. Three weeks later, the mice received boostex injections with either supernatant or sediment which were prepared from 5-10 $\times 10^{6}$ disrupted parasites, and then, after an additional week's time, were challenged with $3,000 \mathrm{RH}$ trophozoites.

\section{Results:}

In the experiments in which incomplete adjuvant was used, only 1 of 28 mice immunized with supernatant, and 1 of 17 mice immunized with sediment survived the $\mathrm{RH}$ challenge. No viable parasite was found in the brains of the 2 survivors. All control mice inoculated with $\mathrm{RH}$ died within 10 days after infection. 
In the complete adjuvant experiments, all of 33 mice died within 2 weeks after the $\mathrm{RH}$ challenge (Table 3 ).

Table 3

Efficaoy of Soluble and Insoluble Fractions of Sonic-disrupted Toxoplasmas in Protecting Mice against Challenge with the RH Strain of T. gondii

\begin{tabular}{l|l|c|c|c|c|c}
\hline \hline \multirow{2}{*}{ Exp. } & Fraction & $\begin{array}{c}\text { Period between } \\
\text { 1st vaccination } \\
\text { and challenge }\end{array}$ & $\begin{array}{c}\text { Number } \\
\text { of } \\
\text { mice }\end{array}$ & \multicolumn{3}{|c}{$\begin{array}{c}\text { Number of mice surviving } \\
\text { challenge }\end{array}$} \\
\cline { 3 - 7 } $1^{*}$ & Control 1 & (normal mice) & 10 & $10(100 \%)$ & 0 & - \\
& Soluble & 4 weeks & 28 & $27(96 \%)$ & $1(4 \%)$ & $1(4 \%)$ \\
& Insoluble & 4 weeks & 17 & $3(18 \%)$ & $1(6 \%)$ & $1(6 \%)$ \\
\hline \multirow{4}{*}{$2^{* *}$} & Control 1 & (normal mice) & 10 & $6(60 \%)$ & 0 & - \\
& Control 2 & (adjuvants only) & 11 & $4(36 \%)$ & $1(9 \%)$ & $1(9 \%)$ \\
& Soluble & 4 weeks & 27 & $12(44 \%)$ & 0 & - \\
& Insoluble & 4 weeks & 6 & $2(33 \%)$ & 0 & - \\
\hline
\end{tabular}

* Vaccines in incomplete adjuvants.

** Vaccines in complete adjuvants.

\section{Effect of Antiserum}

\section{Methods:}

Rabbit antiserum, dye test titer of $1: 16,384$, was injected intraperitoneally into mice in doses of $0.3 \mathrm{ml}$. This was immediately followed by an $\mathrm{RH}$ challenge consisting of $100,3,000$, or 200,000 trophozoites.

In another series of experiments, $10 \mathrm{ml}$ of a toxoplasma suspension containing $6 \times 10^{4}$ or $12 \times 10^{4}$ trophozoites were mixed with $7 \mathrm{ml}$ of a $1: 1,024$ pig antiserum and $3 \mathrm{ml}$ of a normal human serum which served as a souse of complement. This mixture was allowed to incubate for 1 hour, then $0.5 \mathrm{ml}$ aliquots, which contained 1,500 or 3,000 trophozoites, were withdrawn and intraperitoneally inoculated into mice.

\section{Results:}

Of the animals passively immunized with rabbit antiserum, only those mice challenged with the very small number of $100 \mathrm{RH}$ trophozoites showed 13 survivors out of 30 after 3 weeks of infection. Examination of the brains of the surviving mice failed to reveal living parasites. In contrast, only 1 of 20 control mice inoculated with 100 trophozonites survived 3 weeks of infection.

In the experiment where living parasites were incubated in the mixture of pig antiserum and normal human serum before inoculation into the experimental animals, only 9 of 80 mice managed to survive for 2 weeks of infection. 
None of the mice survived for 3 weeks of infection. These data are listed in Table 4.

Table 4

Efficacy of Antiserum in Protecting Mice against Challenge with $R H$ Strain of $T$. gondii

\begin{tabular}{|c|c|c|c|c|c|}
\hline \multirow{2}{*}{ Antiserum used } & \multirow{2}{*}{$\begin{array}{l}\text { No. of RH } \\
\text { trophozoites } \\
\text { in challenge }\end{array}$} & \multirow{2}{*}{$\begin{array}{c}\text { Number } \\
\text { of } \\
\text { mice }\end{array}$} & \multicolumn{3}{|c|}{ No. of mice surviving } \\
\hline & & & $1 \mathrm{wk}$ & 2 wks & 3 wks \\
\hline \multirow{3}{*}{ Control mice } & 100 & 20 & $20(100 \%)$ & $1(5 \%)$ & $1(5 \%)$ \\
\hline & 3,000 & 30 & $29(97 \%)$ & 0 & - \\
\hline & 200,000 & 20 & 0 & - & - \\
\hline \multirow{3}{*}{ Rabbit } & 100 & 30 & $30(100 \%)$ & $16(53 \%)$ & $13(43 \%)$ \\
\hline & 3,000 & 50 & $50(100 \%)$ & 0 & - \\
\hline & 200,000 & 30 & 0 & - & - \\
\hline \multirow{2}{*}{ Control mice } & 1,500 & 20 & $19(95 \%)$ & 0 & - \\
\hline & 3,000 & 20 & $17(85 \%)$ & 0 & - \\
\hline \multirow{2}{*}{ Pig* $\left\{\begin{array}{l}\text { group a } \\
\text { group b }\end{array}\right.$} & 1,500 & 40 & $38(95 \%)$ & $7(18 \%)$ & 0 \\
\hline & 3,000 & 40 & $38(95 \%)$ & $2(5 \%)$ & 0 \\
\hline
\end{tabular}

* Plus normal human serum as a souce of complement.

\section{Effect of Cells from Immune Mice}

\section{Methods:}

Peritoneal macrophages were obtained from Beverley infected mice which had survived a subsequent $\mathrm{RH}$ challenge. These mice received an intraperitoneal injection of glycogen to stimulate a peritoneal exudate, which was then collected 4 days later by washing the abdominal cavity in Hanks' solution. The exudate thus collected was centrifuged for 4 minutes at $1,000 \mathrm{rpm}$, resuspended in saline, and inoculated into the recipient mice in aliquots of 12 and $17 \times 10^{6}$ macrophages per mouse. Four days later, the recipient mice were challenged with either 100 or $3,000 \mathrm{RH}$ trophozoites. As one control, $12 \times 10^{6}$ peritoneal macrophages from normal mice were transfered into recipient mice, which were later challenged with $3,000 \mathrm{RH}$ parasites. As another control, normal mice were intraperitoneally inoculated with $3,000 \mathrm{RH}$ parasites.

In another series of experiments, small diffusion chambers were used to elucidate whether or not parasites were able to invade immune macrophages. The chamber was made of vinyl-risin tubing $18 \mathrm{~mm}$ in diameter, $5 \mathrm{~mm}$ long, and with a very small hole in its wall. Both ends were sealed up with HA milipore filters $(0.45 \pm 0.02 \mu)$ by Cemedain No. 216 . The chambers were sterilized 
in an ethylene oxide gas chamber for 24 hours. Into each small diffusion chamber, $0.6 \mathrm{ml}$ amount of suspension was inoculated. The $0.6 \mathrm{ml}$ amount consisted of $0.2 \mathrm{ml}$ of toxoplasma suspension containing $5 \times 10^{6} \mathrm{RH}$ trophozoites obtained from a guinea pig; $0.2 \mathrm{ml}$ of normal mouse serum; and $0.2 \mathrm{ml}$ of immune mice macrophage suspension containing $10 \times 10^{6}$ cells. In addition, the suspension also contained 500 units of penicillin, and $500 \gamma$ of streptomycin. Immediately after loading a chamber, it was inserted into the abdominal cavity of a mouse.

The antiserum against guinea pig macrophage, which was prepared previously" to destroy its macrophages, was injected into these mice intraperitoneally immediately after the insertion. The chambers were left in place 1 to 5 days, and then removed. The percentage of toxoplasma-infected macrophages was determined microscopically by fresh smears and Giemsa-stained smears. As a control, $10 \times 10^{6}$ peritoneal macrophages from normal mice were used in the same procedure as that used in the experimental mice. In order to check whether or not the parasites in the chambers survived, $0.4 \mathrm{ml}$ of the contents of each chamber was inoculated into normal mice.

Results:

The transfer of peritoneal macrophages from immune to non-immune mice failed to confer any sort of immunity on the recipient mice. Almost all of the experimental and control mice died within 2 weeks. Only one mouse died after 16 days (Table 5).

Table 5

Survival of Mice iv Challenged with $R H$ Trophozoites 4 Days after the Transfer of immune Macrophages

\begin{tabular}{l|c|c|c|c|c}
\hline \multirow{2}{*}{$\begin{array}{c}\text { No. of transfer } \\
\text { macrophages }\end{array}$} & \multirow{2}{*}{$\begin{array}{c}\text { No. of parasites } \\
\text { in challenge }\end{array}$} & \multirow{2}{*}{$\begin{array}{c}\text { No. of } \\
\text { mice }\end{array}$} & \multicolumn{4}{|c}{ Mice surviving } \\
\cline { 3 - 6 } & & 8 & $6(75 \%)$ & $1(13 \%)$ & 0 \\
\hline $12 \times 10^{6}$ & 100 & 9 & $9(100 \%)$ & 0 & - \\
Control 2 & & 38 & $9(24 \%)$ & 0 & - \\
\hline $17 \times 10^{\circ}$ & & 30 & $14(47 \%)$ & 0 & - \\
Control 2 & 3,000 & 12 & $10(83 \%)$ & 0 & - \\
Control 1 & & & & & \\
\hline
\end{tabular}

Control 1: Mice challenged with $\mathrm{RH}$ parasites after the transfer of $12 \times 10^{6}$ macrophages from normal mice.

Control 2: Mice inoculated with $\mathrm{RH}$ parasites only.

In the diffusion chamber series of experiments, the chambers were removed from the experimental mice after periods ranging from 1 to 5 days, and the 
percentage of macrophages infected with Toxoplasma determined. The macrophages from normal mice showed a more rapid drop in numbers, and a higher infection percentage, than did the macrophages from immune mice (Table 6). In the chambers withdrawn after 1 day, only small numbers of free trophozoites were detected in either group. However, from the second day on, free trophozoites were detected in increasing numbers in chambers containing normal macrophages, but not in the chambers containing macrophages from immune mice.

Table 6

Invasion of Toxoplasmas into Macrophages of Immune Mice by Diffusion Chamber Method

\begin{tabular}{l|c|c|c|c}
\hline \hline Macrophages used & $\begin{array}{c}\text { Days in } \\
\text { peritoneal } \\
\text { cavity }\end{array}$ & $\begin{array}{c}\text { No. of } \\
\text { mice } \\
\text { examined }\end{array}$ & $\begin{array}{c}\text { Average no. of } \\
\text { macrophages } \\
\text { recovered in } \\
\text { chamber }\end{array}$ & $\begin{array}{c}\text { Percentage of } \\
\text { infected } \\
\text { macrophages }\end{array}$ \\
\hline \multirow{5}{*}{ Immune } & 1 day & 3 & $328 / 0.1 \mathrm{~mm}^{3}$ & 25 \\
& 2 & 3 & 116 & 27 \\
& 3 & 3 & 67 & 37 \\
& 5 & 2 & 45 & 27 \\
Normal (control) & 5 & 2 & 33 & 15 \\
& 1 & 3 & 553 & 36 \\
& 3 & 3 & 140 & 72 \\
& 4 & 3 & 35 & 46 \\
\hline
\end{tabular}

Original numbers of immune and normal macrophages in one chamber were $1,700 / 0.1 \mathrm{~mm}^{3}$.

In addition to the direct examination of chambers, $0.4 \mathrm{ml}$ of suspension was withdrawn from every chamber and subinoculated into normal mice. Regardless of the source of the subinoculum, all the subinoculated mice died within 10 days, demonstrating the presence of viable $\mathrm{RH}$ trophozoites in every chamber, even after 5 days of contact with immune macrophages.

\section{DISCUSSION}

In the present study, experiments were made to determine the effect of different immunization procedures against a toxoplasma challenge. Heatkilled toxoplasma vaccine was given to mice. Following a series of 4 injections, 1 group of immunized mice demonstrated some higher resistance to 
the challenge infection than the controls. In this group, 5 of 43 immunized mice survived the challenge for more than 3 weeks, though they had living parasites in their brains by the post-mortem examination. However, this effect was observed in only 1 of 5 groups of mice. Following the administration of vaccine in complete and incomplete adjuvants, a similar lack of protection against challenge was observed. Senaga (1957) reported that there was no prolongation of the survival time of mice injected with killed vaccine, in case of guinea pigs, however, half of 6 vaccinated animals survived a challenge with RH. Wildführ (1957) reported that rabbits were protected against the challenge of one million living parasites after 16 parenteral inoculations with killed parasites. However, Stahl (1964) reported that the administration of a killed vaccine in Freud's complete adjuvants did not produce protection against a challenge with $\mathrm{RH}$ parasites. According to Cutchins et al (1956) and Beattie (1963), the administration of killed vaccine was more effective in producing antibody, but it was little effective for protection of animals from death. The results of the present report are concurrent with these latter studies, in that a toxoplasma vaccine, with or without adjuvant, did not protect mice against a subsequent challenge with the lethal $\mathrm{RH}$ strain.

In this study, both soluble and insoluble fractions of parasites disrupted by sonic vibration were shown to have no protective effect against toxoplasma challenge. Cutchins et al (1956) reported that the antigen was apparently associated with the whole toxoplasma rather than its extracts, even though the latter actively fixed complement, and the vaccinated animals were immune only to intradermal and intraperitoneal inoculation, not intracerebral challenge. Of the toxoplasma lysate, Lunde et al (1964) reported that the intravenous injection of it was toxic to rabbits causing death in 6 to 24 hours. However, rabbits with chronic toxoplasmosis showed resistance to the lethal effect of the lysate.

Wildführ (1957) reported that effective protection could not be obtained in hamsters after passive immunization with rabbit immune serum, only a prolongation of survival time ranging from 15 to 19 days were observed. In the present experiment in mice, almost similar results were obtained, showing that about half of the mice injected with immune serum could survive a challenge with $100 \mathrm{RH}$ parasites for 3 weeks or more. However, neither prolongation of survival or protection was seen following challenge with 3,000 trophozoites. The combined administration of antiserum and normal human serum was not noticeably different from the effects of antiserum alone. Eichenwald (1949) stated that antiserum had some beneficial action, and in combination with sulfadiazine was considerably more effective than either used alone. As is 
herein described, it seems that the administration of antiserum has little effect in protecting mice against a lethal challenge.

It is important to elucidate whether or not a cellular immunity is developed following a toxoplasma infection. Peritoneal macrophages obtained from immune mice were cultivated with living parasites in diffusion chambers inserted in the peritoneal cavity of normal mice. The present experiments indicated that there was a suppression in the development of parasites associated with immune macrophages, but not with normal macrophages. After the transfer of immune macrophages, however, neither protection nor prolongation of survival time were found in mice challenge with $\mathrm{RH}$ parasites. According to Visher et al (1954), toxoplasma immune cells which were cultivated in vitro, inhibited intracellular multiplication of parasite, and complete prevention was found after the combined administration with immune cells and antiserum in vitro. With Trichinella spiralis, Larsh et al (1964) stated that transfer of peritoneal exudate cells trom infected mice to normal mice caused a significant acceleration in removing adult worms from a challenge infection.

Under the conditions of the experiments described in this report, attempts to immunize mice artificially, either by the injection of toxoplasma vaccines or by the transfer of peritoneal exudate cells from immune mice, were not successful.

\section{SUMMARY}

1. Toxoplasma vaccines were prepared from whole and sonically-disrupted organisms, and administered to mice with or without Freund's adjuvants. None of these vaccines proved effective against a subsequent challenge with the lethal RH strain of Toxoplasma gondii.

2. Passive immunization of mice with rabbit and pig antisera likewise failed to protect mice against a $\mathrm{RH}$ challenge.

3. The passive transfer of peritoneal exudate cells from immune to nonimmune mice was ineffective, although diffusion chamber studies indicated that immune macrophages were able to inhibit the growth and multiplication of $\mathrm{RH}$ trophozoites.

\section{A.CKNOWLEDGEMENT}

The author acknowledges with thanks the valuable advice of Dr. Hisakichi Matsubayashi, Professor of Parasitology, School of Medicine, Keio University, and is also deeply indebted to Dr. Takehisa Akiyama, Instructor of Department of Microbiology, Keio University, for his valuable advice and suggestions. 


\section{REFERENCES}

1. Beattie, C. P.: Immunity to Toxoplasma. In: Immunity to Protozoa edited by P. C. C. Garnham, A. E. Peirce, and I, Roitt. Blackwell Scientific Pub., Oxford, $253-258,1963$.

2. Beverley, J. K. A.: A rational approach to the treatment of toxoplasmic uveitis. Trans. Ophth. Soc. 78: 109-121, 1958.

3. Cutchins, E. C., and Warren, J.: Immunity pattern in the guinea pig following 'f'oxoplasma infection and vaccination with killed Toxoplasma. Am. J. 'Trop. Med. Hyg. 5: 197-209, 1956.

4. Eichenwald, H.: Experimental toxoplasmosis. II. Effect of sulfadiazine and antiserum on congenital toxoplasmosis in mice. Proc. Soc. exp. Biol. Med. 71: $45-49,1949$.

5. Frenkel, J. K.: Host, strain and treatment variation as factors in the pathogenesis of toxoplasmosis. Am. J. Trop. Med. Hyg. 2: 390-415, 1953.

6. F'renkel, J. K.: Pathogenesis of toxoplasmosis and of infections with organisms resembling Toxoplasma. Ann. N.Y. Acad. Scien. 64: 215-251, 1956.

7. Jacobs, L.: The biology of Toxoplasma. Am. J. Trop. Med. Hyg. 2: 365-389, 1953.

8. Larsh, J. E., Goulson, H. T. and Weatherly, N. F.: Studies on delayed (cellular) hypersensitivity in mice infected with Trichinella spiralis. II. Transfer of peritoneal exudate cells. J. Parasit. 50: 496-498, 1964.

9. Lunde, M. N. and Jacobs, L.: Properties of Toxoplasma lysates toxic to rabbits on intravenous injection. J. Parasit 50: 49-51, 1964.

10. Nakayama, I.: Persistence of the virulent $\mathrm{RH}$ strain of Toxoplasma gondii in the brain of immune mice. Keio J. Med. 13: 7-12, 1964.

11. Ruchman, I. and Johansmann, R. J.: Biological properties of a strain of Toxoplasma recovered from a fatal case of congenital toxoplasmosis. Am. J. Trop. Med. 28: 687-695, 1948.

12. Sato, H.: Animal and bacteria. In: On the Immunity to toxoplasmosis. Nankodo, 124-130, 1963. (in Japanese)

13. Senaga, R.: Studies on chronic toxoplasmosis. I. An attempt to produce chronic Toxoplasma infection in guinea pigs and mice. Nissin Igaku 44:429-435, 1957. (in Japanese)

14. Stahl W. and Akao, S.: Immunity in experimental toxoplasmosis. Keio J. Med. 13: $1-6,1964$.

15. Ueda, H.: On the virulence and antigenic property of a cyst-produsing strain of Toxoplasma. Keio Igaku 37: 1631-1638, 1960. (in Japanese)

16. Vischer, W. A. and Suter, E.: Intracelluler multiplication of Toxoplasma gondii in adult mammalian macrophages cultured in vitro. Proc. Soc. exp. Biol. Med. 36: 413-419, 1954.

17. Weinman, D.: Chronic toxoplasmosis. J. Inf. Dis. 73: 85-92, 1943.

18. Wildführ, G.: Tierexperimentelle Immunitätsversuche mit Toxoplasma gondii. Z. Immunforsch. exp. Therapie, 113: 435-452, 1957. 